\title{
Reduction in Carbon Dioxide Emission and Energy Saving Obtained by Renovation of Building Envelope of Existing Residential Buildings
}

\author{
Rui Chen, Xiaoping Feng*, Chengjing Li, Huapeng Chen \\ School of Environment and Civil Engineering, Jiangnan University, Wuxi 214122, China
}

\begin{abstract}
Reducing energy consumption and carbon dioxide $\left(\mathrm{CO}_{2}\right)$ emissions in the construction industry is integral to solving environmental issues, which affect the whole of society and have become increasingly prominent. We selected a residential dwelling from the many buildings in southern Jiangsu Province, China, which consume and emit extremely large amounts of energy and $\mathrm{CO}_{2}$, respectively, and assessed various energy-saving renovation schemes for improving the thermal envelope. First, we used energy consumption simulation software (BESI) to individually analyze the energy performance of each scheme. Then, setting the static payback period as the evaluation index, we applied the orthogonal test method to determine the economic efficiency of different combinations of schemes. Finally, we identified the optimal combination for conserving energy and decreasing $\mathrm{CO}_{2}$ emissions as 120 -mm-thick expanded polystyrene insulating board for both the exterior wall and the roof, and 5-mm-thick triple-silver low-emissivity glass and 5-mm-thick normal glass separated by $12 \mathrm{~mm}$ of air for the exterior windows, which resulted in a cooling capacity, heating consumption, total building energy consumption, static payback period, and dynamic payback period of $28.37 \mathrm{kWh} \mathrm{m}^{-2} \mathrm{a}^{-1}, 4.22 \mathrm{kWh} \mathrm{m}^{-2} \mathrm{a}^{-1}, 32.59 \mathrm{kWh} \mathrm{m}^{-2} \mathrm{a}^{-1}, 13.76$ years, and 22.84 years, respectively, as well as an annual reduction in $\mathrm{CO}_{2}$, sulfur dioxide $\left(\mathrm{SO}_{2}\right)$, and nitrogen oxides $\left(\mathrm{NO}_{x}\right)$ emissions of 86.01 tons, 2.59 tons, and 1.29 tons, respectively.
\end{abstract}

Keywords: Building envelope, Energy-saving renovation, Carbon dioxide emission, Energy consumption simulation, Economical and environmental benefit

\section{OPEN ACCESS}

Received: April 25, 2021

Revised: June 24, 2021

Accepted: June 24, 2021

${ }^{*}$ Corresponding Author: fxp@jiangnan.edu.cn

\section{Publisher:}

Taiwan Association for Aerosol Research

ISSN: $1680-8584$ print ISSN: 2071-1409 online

Copyright: The Author(s). This is an open access article distributed under the terms of the Creative Commons Attribution License (CC BY 4.0), which permits unrestricted use, distribution, and reproduction in any medium, provided the original author and source are cited.

\section{INTRODUCTION}

With the rapid development of social economy, the increasing scale of urbanization and the improvement of people's requirements for living comfort, there is an increasing demand for energy and favorable environment. Energy plays a crucial role in facilitating development in a country (Beidari et al., 2017). One of the essential priorities for society's future is the sustainable development and provision of projects that actualize sustainable principles (Puko et al., 2020). Compared with the chemical industry, transportation and other related fields, the construction industry has a great prospect in both reducing energy consumption and coping with climate change in present world. According to the International Energy Agency (IEA), buildings and building construction sectors together consume $36 \%$ of the total global energy consumption and are responsible for almost $40 \%$ of direct and indirect greenhouse gas (GHG) emissions (Hamburg and Kalamees, 2019; Mancini and Nastasi, 2019; Tokbolat et al., 2019; Mahmoodzadeh et al., 2020; Mejjaouli and Alzahrani, 2020). Currently, around 35\% of buildings in Europe are over 50 years old. Meanwhile, they are responsible for $40 \%$ of energy consumption and $36 \%$ of GHG emissions in the European Union (Hamburg and Kalamees, 2019). Up to 2018, the energy used in construction and operation of buildings in China accounted for $37 \%$ of the total social energy consumption, of which the energy used in construction accounted for about $14 \%$ and operation of buildings accounted for about 23\% (Yu et al., 2009). Therefore, to reduce the pressure of building energy 
demand and carbon dioxide emissions, one not only needs to pay attention to the energy consumption of new buildings in the construction stage. How to save the operation energy consumption of existing buildings has more practical significance for energy saving in buildings. During the last decades, architects have gradually embraced a trend that energy efficiency should be maximized as much as possible, resulting in the growing number of passive houses being built (Szirtesi and Igaz, 2016).

A substantial part of the energy demand of residential buildings is due to fossil-fuel-powered space and domestic hot water heating (Pinto and da Graça, 2018). Improving the thermal envelope of these buildings can effectively reduce the energy use. Building an envelope serves a function other than just being a structural or architectural component (Al-Qahtani and Elgizawi, 2020). It can be designed to provide a healthy and comfortable environment for users.

Studies of the energy-saving renovation and building envelope are progressing a lot. Zhou et al. (2018) investigated the energy-saving potential from the building envelope design and actual operation optimization. Baglivo et al. (2017) highlighted the usefulness of the envelope design optimization that is characterized by high values of heat storage capacity, enabling internal temperature fluctuations to be kept under control, especially during summer. Ahmed and Asif (2020) proposed a three-level energy retrofit scheme, including enhancing the efficiency of air conditioning system and thickening envelope insulation. Results indicated that annual energy consumption in a villa is reduced by $13.79 \%, 19.27 \%$ and $56.9 \%$, and in the apartment building by $22.84 \%, 28.85 \%$ and $58.5 \%$ through different retrofit levels. Tan et al. (2019) identified that the energy-saving rate of building envelope integrating green plants is $25 \%$. Chen et al. (2017) concluded key energy-saving measures on the reconstruction of envelope enclosure, water supply, drainage system and lighting system, and renewable energy use for existing residential buildings in hot summer and cold winter zone. And the envelope renovation should be given a high-priority order.

Energy relates to economic growth by being a basic necessity that fuels the daily consumption of an economy (Lee and Rosalez, 2017). The combustion of a large number of fossil fuels leads to excessive emissions of $\mathrm{CO}_{2}$. At present, the amount of $\mathrm{CO}_{2}$ in the atmospheres is nearly $50 \%$ higher than in 1750 (Su et al., 2020). $\mathrm{CO}_{2}$ emissions have globally received more and more attention, including greenhouse effects, health of ecosystems, radiative forcing, global carbon cycle, reduction of $\mathrm{CO}_{2}$ emissions, as well as $\mathrm{CO}_{2}$ capture and geological storage (Cai et al., 2019; Xiang et al., 2019; Yang et al., 2019). Atmospheric quality deterioration has occurred in Asian, European and North American cities in recent years, and especially in some rapidly developing regions and countries (Li et al., 2018).

Existing buildings in southern Jiangsu Province, China, have large stocks. Meanwhile, the people here have higher requirements for living comfort. In this study, the existing residential buildings in southern Jiangsu Province are taken as the research object, the effect of building envelope renovation on energy consumption is analyzed by energy consumption simulation software BESI, and the economy of renovation schemes is analyzed through orthogonal test method.

\section{METHODS}

\subsection{Project Overview}

The building is located in the city of Wuxi, Jiangsu Province, with a total height of $23.75 \mathrm{~m}$, a total area of $5197.12 \mathrm{~m}^{2}$ and a shape coefficient of 0.244 . Sustainable buildings and building information modeling are two future cornerstones of the architectural, engineering and construction industry (Liu et al., 2020a). The software BESI is used to extract the building data of the established model. The area of window and wall in each direction of the existing building, the practice of envelope enclosure and the current situation of annual energy consumption and carbon dioxide emissions are shown in Tables 1, 2 and 3. The layout and simulation model of the building standard floor are shown in Figs. 1 and 2.

\subsection{Parameter Setting}

The simulation of energy consumption does not consider the energy consumption required by lighting equipment, considers the annual change of energy consumption caused by the structural change of building envelope alone. The average personnel density of the building is $30 \mathrm{~m}^{2}$ person ${ }^{-1}$. 
Table 1. Table of the area of window and wall of the existing building.

\begin{tabular}{llll}
\hline Orientation & $\begin{array}{l}\text { The Area of the } \\
\text { External Window }\left(\mathrm{m}^{2}\right)\end{array}$ & $\begin{array}{l}\text { The Area of the } \\
\text { External Wall }\left(\mathrm{m}^{2}\right)\end{array}$ & $\begin{array}{l}\text { The Area of } \\
\text { the Roof }\left(\mathrm{m}^{2}\right)\end{array}$ \\
\hline East & 70.84 & 329.18 & 0.22 \\
South & 427.20 & 1080.80 & 0.40 \\
West & 75.72 & 416.68 & 0.19 \\
North & 343.56 & 1201.20 & 0.29 \\
\hline
\end{tabular}

Table 2. Components of building envelope before renovation.

\begin{tabular}{lll}
\hline Building Envelope & $\begin{array}{l}\text { Overview of Components } \\
\text { (from Top to Bottom) }\end{array}$ & $\begin{array}{l}\text { Heat Transfer Coefficient } \\
\left(\mathrm{W} \mathrm{m}^{-2} \mathrm{~K}^{-1}\right)\end{array}$ \\
\hline External wall & $\begin{array}{l}\text { Mixed mortar: } 20 \mathrm{~mm} \\
\text { Solid clay brick: } 240 \mathrm{~mm} \\
\text { Mixed mortar: } 20 \mathrm{~mm}\end{array}$ & \\
External window & Single glazed aluminum window & 6.40 \\
Slope roof & Cement tile & 1.59 \\
& Roof batten & \\
& Waterproof layer & \\
& Plank sheathing & \\
& Purlin & 1.76 \\
Flat roof & Cement mortar: $20 \mathrm{~mm}$ \\
& Waterproof layer \\
& Vermiculite concrete: $40 \mathrm{~mm}$ \\
& Roof board: $120 \mathrm{~mm}$ \\
& Lime mortar: $10 \mathrm{~mm}$ & \\
&
\end{tabular}

Table 3. Annual energy consumption status and carbon dioxide emissions of buildings before renovation.

\begin{tabular}{llll}
\hline & $\begin{array}{l}\text { Energy Consumption } \\
\left(\mathrm{kWh} \mathrm{m}^{-2}\right)\end{array}$ & $\begin{array}{l}\text { Power Consumption } \\
\left(\mathrm{kWh} \mathrm{m}^{-2}\right)\end{array}$ & $\begin{array}{l}\text { Carbon Dioxide Emissions } \\
(\mathrm{t})\end{array}$ \\
\hline Cooling & 40.35 & 17.54 & 90.89 \\
Heating & 25.87 & 13.62 & 70.57 \\
Total & 66.22 & 31.16 & 161.46 \\
\hline
\end{tabular}

The built-in parameters of the model are set according to the local climate conditions and the "Energy-saving Design Standard for Residential Buildings in Hot Summer and Cold Winter Areas." The indoor designed temperature and humidity in summer are separately $40 \%$ and $26^{\circ} \mathrm{C}$, while in winter, the indoor designed temperature and humidity are $60 \%$ and $24^{\circ} \mathrm{C}$. The air conditioning system parameters are set as shown in Table 4.

According to the recommended value of heat transfer coefficient of building envelope in the "Technical Guidelines for Passive Ultra-Low Energy Consumption Green Building (Trial) (Residential Building)" (hereinafter referred to as the "Guidelines"), the upper limit of heat transfer coefficient of building envelope in the hot summer and cold winter area is taken as the reference value of this test. Reference value of upper limit of heat transfer coefficient of external wall and roof are both $0.2-0.35$, which of external window is 1.0-2.0.

\section{RESULTS AND DISCUSSION}

\subsection{Analysis of Effect of Energy-saving Transformation of Building Envelope}

\subsubsection{Analysis of effect of energy-saving renovation of external wall}

The area of the external wall takes a large proportion in total area of the building envelope. In 


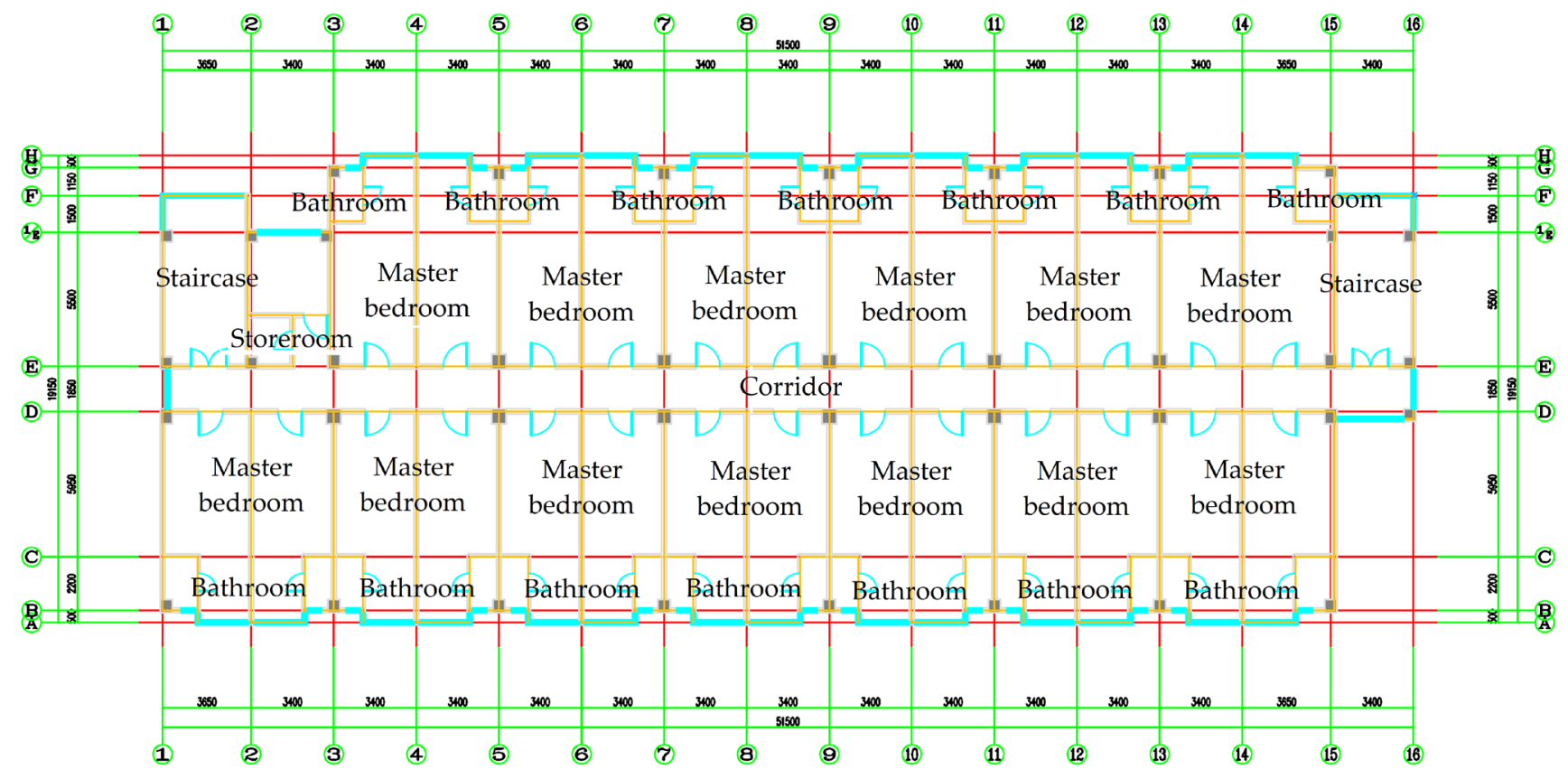

Fig. 1. Layout plan of existing building standard floor.

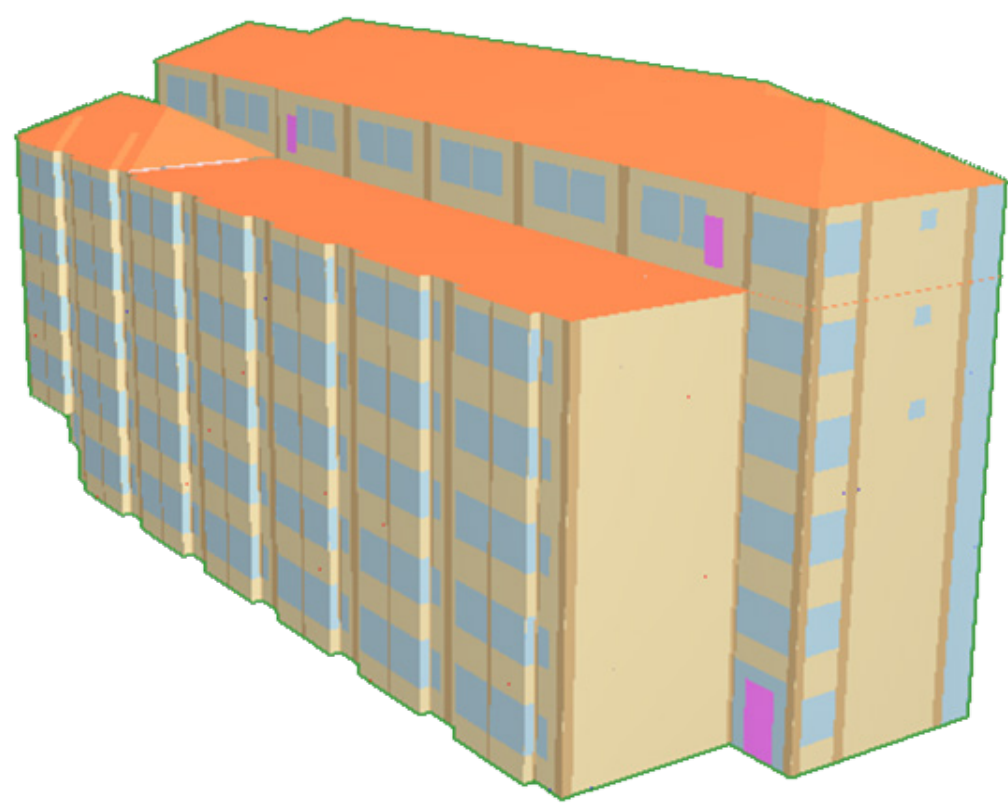

Fig. 2. Layout plan of existing building standard floor.

Table 4. Parameter setting of air conditioning system.

\begin{tabular}{llll}
\hline Function & Equipment & COP & Operation Schedule of Air Conditioning \\
\hline Cooling & Household split air conditioning & 1.9 & December 1 (current year)-February 28 (next year) \\
Heating & Household split air conditioning & 2.3 & June 15 (current year)-August 31 (next year) \\
\hline
\end{tabular}

order to explore the impact of the energy-saving reconstruction degree of the external wall on the building energy consumption, the energy-saving renovation effect of the external wall is analyzed separately. When analyzing the effect of external wall renovation, the specification of the roof and the external window before renovation is kept to realize the qualitative analysis of a single variable. 
In this study, expanded polystyrene (EPS) insulating board is applied to renovating the external wall of existing buildings. Determination of the thickness of EPS insulating board and its corresponding heat transfer coefficient should take advantage of the reference value of upper limit of heat transfer coefficient of building envelope and the formula of average heat transfer coefficient, as shown in Eq. (1). For example, when the heat transfer coefficient of the external wall is $0.198 \mathrm{~W} \mathrm{~m}^{-2} \mathrm{~K}^{-1}$, the thickness of EPS insulation board of the external wall is $220 \mathrm{~mm}$ :

$K_{m}=\frac{K_{P} \cdot F_{P}+K_{B 1} \cdot F_{B 1}+K_{B 2} \cdot F_{B 2}+K_{B 3} \cdot F_{B 3}}{F_{P}+F_{B 1}+F_{B 2}+F_{B 3}}$

where $K$ is equal to $K_{m}$ (in areas with hot summers and cold winters); $K_{m}$ is the mean heat transfer coefficient of external wall; $K_{p}$ is the mean heat transfer coefficient of the main part of external wall; $K_{B 1}, K_{B 2}, K_{B 3}$ are the heat transfer coefficient of thermal bridges; $F_{p}$ is the area of the main part of external wall; $F_{B 1}, F_{B 2}, F_{B 3}$ are the area of thermal bridges.

Starting at the external wall before renovation, taking $20 \mathrm{~mm}$ as the step length, the external wall renovation scheme $Q_{1}-Q_{12}$ is obtained. The relevant data of the relationship between the heat transfer coefficient of the external wall of the existing building and the thickness of the insulation board are shown in Table 5 .

After the analysis of each plan, the trend of data change is shown in Fig. 3. It can be seen that the heat transfer coefficient of external wall generally decreases when the thickness of insulation layer increases. However, with the continuous increase of the thickness of insulation layer, the change trend of heat transfer coefficient slows down gradually, and even reaches the result of a straight line. According to the curve trend, when the thickness of EPS insulation board reaches more than $200 \mathrm{~mm}$, the change range of heat transfer coefficient is small.

The above external wall energy-saving renovation scheme is calculated and analyzed one by one, in order to obtain the energy-saving effect on each thickness of EPS insulating board. The calculation of energy consumption of the building's annual cooling consumption, heating consumption, total energy consumption and carbon dioxide emissions of the external wall renovation schemes are shown in Table 6.

According to the results of energy consumption of each renovation scheme, the total energy consumption of each plan and the energy-saving effect achieved are compared, as shown in Fig. 4. For the energy-saving transformation of the external wall, the increase of the thickness of EPS insulation layer can bring the decline of the total annual energy consumption of the building, which also shows that the better the energy-saving effect. However, with the continuous increase of insulation layer thickness, the growth rate of energy-saving rate slows down gradually and tends to a linear state. It shows that increasing the thickness of insulation layer will not increase

Table 5. Energy-saving and carbon dioxide emissions reduction renovation scheme of existing building external wall.

\begin{tabular}{|c|c|c|}
\hline Renovation Scheme & $\begin{array}{l}\text { The Thickness of EPS } \\
\text { Insulation Board (mm) }\end{array}$ & $\begin{array}{l}\text { Heat Transfer Coefficient } \\
\left(\mathrm{W} \mathrm{m}^{-2} \mathrm{~K}^{-1}\right)\end{array}$ \\
\hline Before renovation & 0 & 1.736 \\
\hline$Q_{1}$ & 20 & 1.018 \\
\hline$Q_{2}$ & 40 & 0.72 \\
\hline$Q_{3}$ & 60 & 0.557 \\
\hline$Q_{4}$ & 80 & 0.454 \\
\hline$Q_{5}$ & 100 & 0.383 \\
\hline$Q_{6}$ & 120 & 0.332 \\
\hline$Q_{7}$ & 140 & 0.292 \\
\hline$Q_{8}$ & 160 & 0.261 \\
\hline$Q_{9}$ & 180 & 0.236 \\
\hline$Q_{10}$ & 200 & 0.215 \\
\hline$Q_{11}$ & 220 & 0.198 \\
\hline$Q_{12}$ & 240 & 0.183 \\
\hline
\end{tabular}




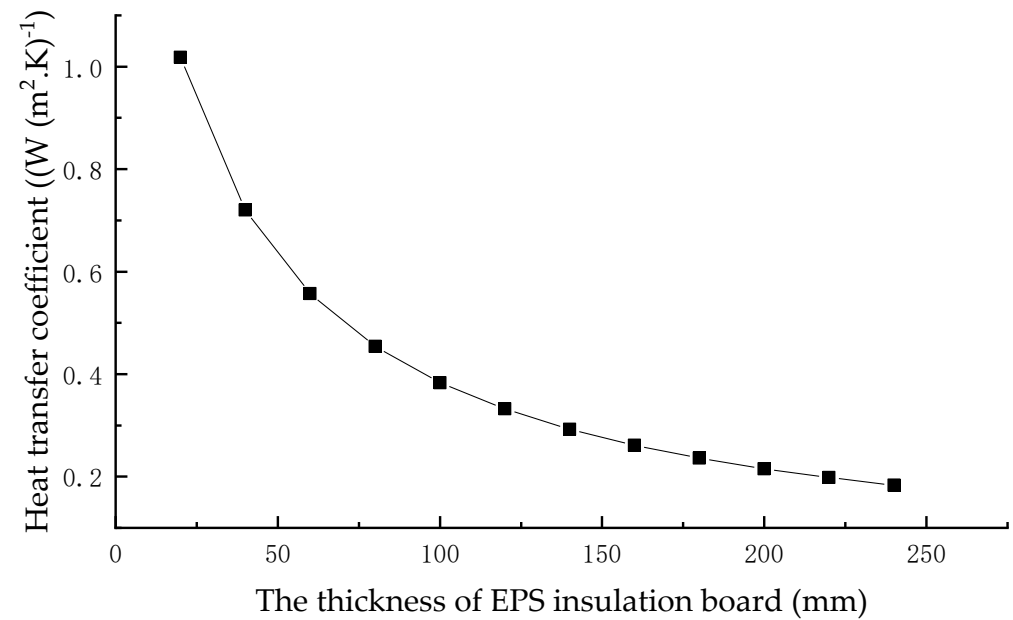

Fig. 3. Trend of the heat transfer coefficient of external wall.

Table 6. Annual energy consumption and carbon dioxide emissions after external wall renovation.

\begin{tabular}{llllll}
\hline $\begin{array}{l}\text { Renovation } \\
\text { Scheme }\end{array}$ & $\begin{array}{l}\text { Total Energy } \\
\text { Consumption } \\
\left(\mathrm{kWh} \mathrm{m}^{-2}\right)\end{array}$ & $\begin{array}{l}\text { Cooling } \\
\text { Consumption } \\
\left(\mathrm{kWh} \mathrm{m}^{-2}\right)\end{array}$ & $\begin{array}{l}\text { Heating } \\
\text { Consumption } \\
\left(\mathrm{kWh} \mathrm{m}^{-2}\right)\end{array}$ & $\begin{array}{l}\text { Energy-saving } \\
\text { Efficiency }(\%)\end{array}$ & $\begin{array}{l}\text { Carbon Dioxide } \\
\text { Emissions } \\
(\mathrm{t})\end{array}$ \\
\hline Pre-renovation & 66.22 & 40.35 & 25.87 & 0.00 & 161.46 \\
$Q_{1}$ & 60.12 & 38.29 & 21.83 & 9.21 & 146.59 \\
$Q_{2}$ & 57.48 & 37.42 & 20.06 & 13.20 & 140.15 \\
$Q_{3}$ & 56.00 & 36.94 & 19.05 & 15.43 & 136.54 \\
$Q_{4}$ & 55.05 & 36.64 & 18.41 & 16.87 & 134.22 \\
$Q_{5}$ & 54.40 & 36.43 & 17.97 & 17.85 & 132.64 \\
$Q_{6}$ & 53.92 & 36.28 & 17.64 & 18.57 & 131.47 \\
$Q_{7}$ & 53.55 & 36.16 & 17.38 & 19.13 & 130.57 \\
$Q_{8}$ & 53.25 & 36.07 & 17.18 & 19.59 & 129.84 \\
$Q_{9}$ & 53.02 & 36.00 & 17.02 & 19.93 & 129.28 \\
$Q_{10}$ & 52.81 & 35.93 & 16.88 & 20.25 & 128.76 \\
$Q_{11}$ & 52.66 & 35.88 & 16.78 & 20.48 & 128.40 \\
$Q_{12}$ & 52.51 & 35.93 & 16.68 & 20.70 & 128.03 \\
\hline
\end{tabular}

the energy-saving benefit of external wall significantly, and the increase of insulation layer thickness will cause higher reconstruction cost. Therefore, the economic analysis of insulation thickness should be considered when the existing buildings are reformed for energy conservation.

\subsubsection{Analysis of effect of energy-saving renovation of roof}

Although the area of roof only accounts for a small part of total area of the building envelope, due to its special location, the roof will produce a large difference between indoor and outdoor temperature, resulting in more energy consumption than the external wall of the same area. In addition, in hot summer and cold winter area, energy-saving renovation of the roof can directly improve the indoor environment of the top floor.

In order to find out the impact of roof renovation on the total annual energy consumption, a separate analysis should be carried out on the roof. When analyzing the effect of roof renovation, the specification of the external wall and window before renovation is kept to realize the qualitative analysis of a single variable. The building has flat roof and slope roof, and the heat transfer coefficient of the two is different before reconstruction. However, after energy consumption simulation, the thickness change of EPS insulation board has similar effect on their heat transfer coefficient.

According to the external wall energy-saving renovation analysis and the ceiling reference value of the roof heat transfer coefficient, the roof transformation plan $W_{1}-W_{12}$ is formulated. The concrete values of the roof energy-saving transformation plan are shown in Table 7. 


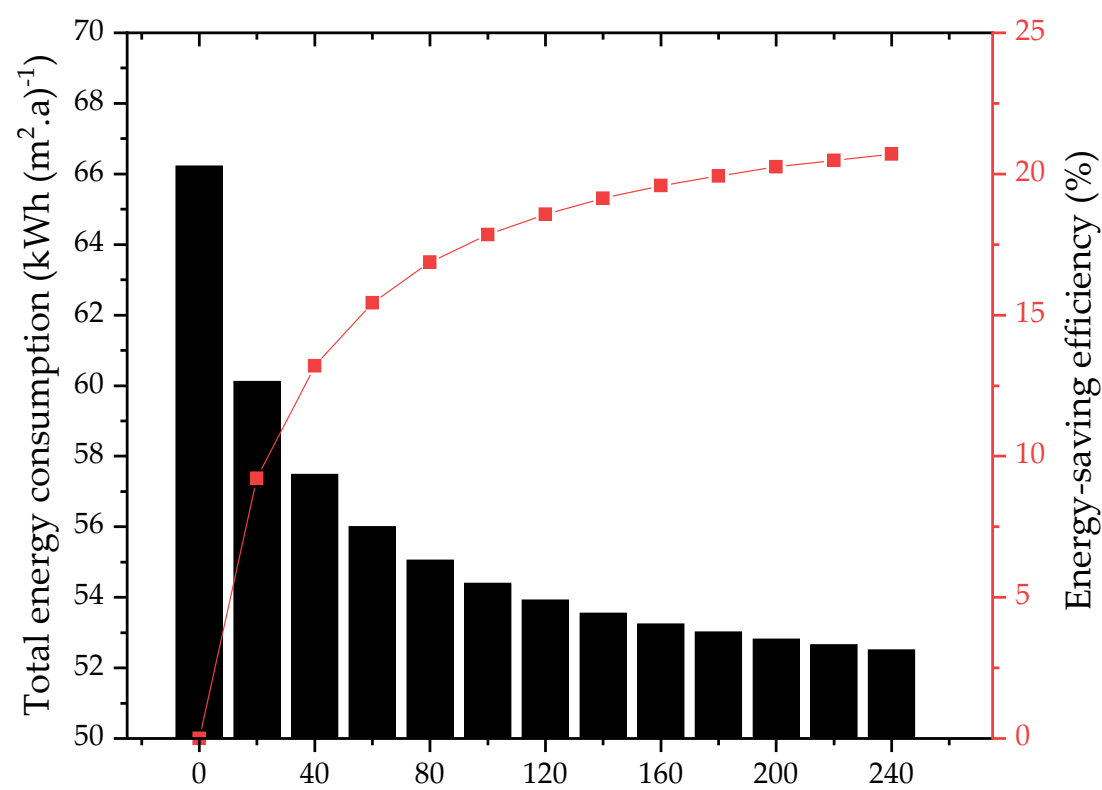

The thickness of EPS insulation board (mm)

Fig. 4. Change diagram of total energy consumption and energy-saving efficiency of external wall renovation scheme.

Table 7. Energy-saving renovation scheme of existing building roof.

\begin{tabular}{lllc}
\hline \multirow{2}{*}{ Renovation Scheme } & The Thickness of EPS & \multicolumn{2}{c}{ Heat Transfer Coefficient $\left(\mathrm{W} \mathrm{m}^{-2} \mathrm{~K}^{-1}\right)$} \\
\cline { 3 - 4 } & Insulation Board $(\mathrm{mm})$ & Flat Roof & Slope Roof \\
\hline Pre-renovation & 0 & 1.761 & 1.587 \\
$W_{1}$ & 20 & 1.026 & 0.965 \\
$W_{2}$ & 40 & 0.724 & 0.693 \\
$W_{3}$ & 60 & 0.559 & 0.541 \\
$W_{4}$ & 80 & 0.456 & 0.443 \\
$W_{5}$ & 100 & 0.385 & 0.376 \\
$W_{6}$ & 120 & 0.333 & 0.326 \\
$W_{7}$ & 140 & 0.293 & 0.288 \\
$W_{8}$ & 160 & 0.262 & 0.258 \\
$W_{9}$ & 180 & 0.237 & 0.233 \\
$W_{10}$ & 200 & 0.216 & 0.213 \\
$W_{11}$ & 220 & 0.198 & 0.196 \\
$W_{12}$ & 240 & 0.184 & 0.182 \\
\hline
\end{tabular}

Combined with Fig. 5 , the analysis of scheme $W_{1}-W_{12}$ in Table 7 shows that although the heat transfer coefficients of flat roof and slope roof are slightly different before renovation, the heat transfer coefficients of both have the same changing trend with the increase of insulation layer thickness, and even almost coincide with each other. Therefore, when considering and analyzing the roof later, the two can be considered as one. The roof is transformed separately, and the trend of change is similar to that of the external wall. When the thickness of EPS insulation layer increases, the heat transfer coefficient of the roof shows a continuous downward trend, but the change of the heat transfer coefficient caused by the increase of the thickness of insulation layer gradually decreases, and even appears in a nearly straight-line state.

Calculating all the schemes of the roof energy-saving renovation one by one, the total energy consumption, cooling consumption, heating consumption and carbon dioxide emissions of the building with different thickness of EPS insulation board are shown in Table 8.

Combined with Fig. 6 , the results of roof energy-saving reconstruction schemes $W_{1}-W_{12}$ in 


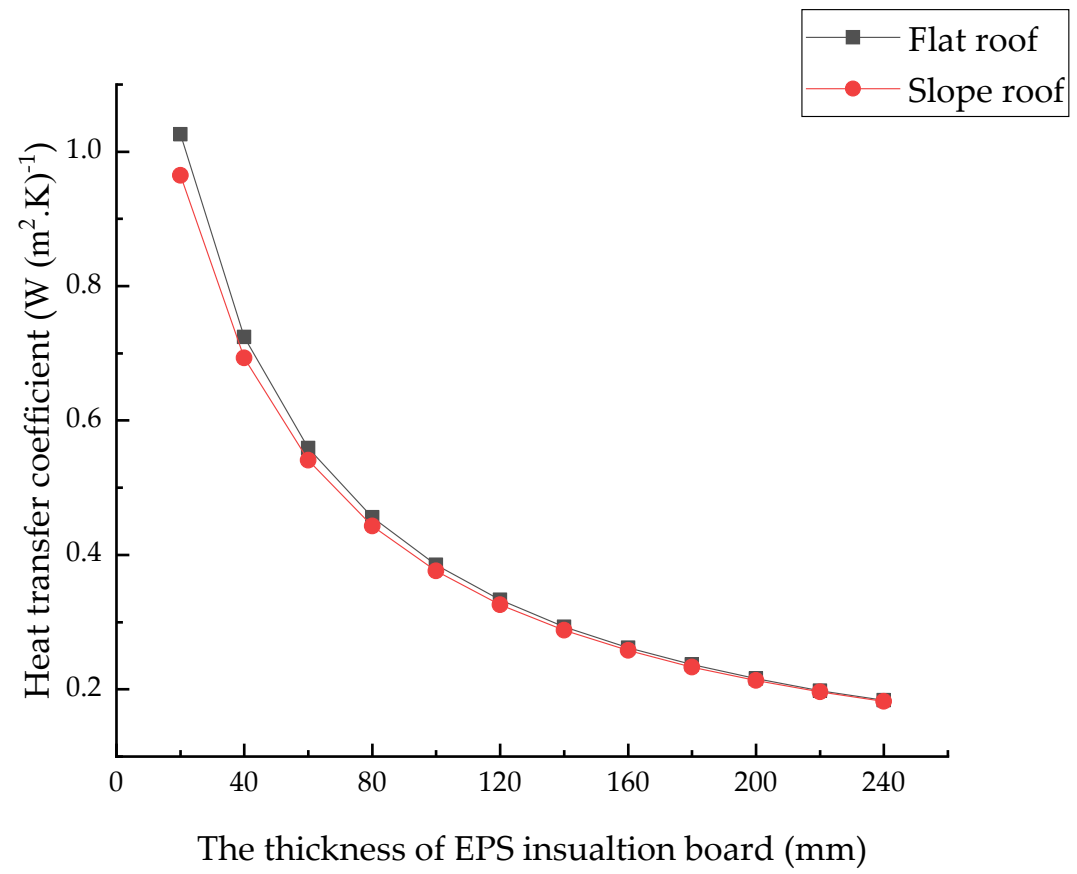

Fig. 5. Trend of the heat transfer coefficient of roof.

Table 8. Annual energy consumption and carbon dioxide emissions after roof renovation.

\begin{tabular}{llllll}
\hline $\begin{array}{l}\text { Renovation } \\
\text { Scheme }\end{array}$ & $\begin{array}{l}\text { Total Energy } \\
\text { Consumption } \\
\left(\mathrm{kWh} \mathrm{m}^{-2}\right)\end{array}$ & $\begin{array}{l}\text { Cooling } \\
\text { Consumption } \\
\left(\mathrm{kWh} \mathrm{m}^{-2}\right)\end{array}$ & $\begin{array}{l}\text { Heating } \\
\text { Consumption } \\
\left(\mathrm{kWh} \mathrm{m}^{-2}\right)\end{array}$ & $\begin{array}{l}\text { Energy-saving } \\
\text { Efficiency } \\
(\%)\end{array}$ & $\begin{array}{l}\text { Carbon Dioxide } \\
\text { Emissions } \\
(\mathrm{t})\end{array}$ \\
\hline Pre-renovation & 66.22 & 40.35 & 25.87 & 0.00 & 161.46 \\
$W_{1}$ & 62.71 & 38.71 & 24 & 5.30 & 152.90 \\
$W_{2}$ & 61.13 & 38 & 23.13 & 7.69 & 149.05 \\
$W_{3}$ & 60.24 & 37.6 & 22.64 & 9.03 & 146.88 \\
$W_{4}$ & 59.66 & 37.35 & 22.31 & 9.91 & 145.47 \\
$W_{5}$ & 59.25 & 37.17 & 22.09 & 10.53 & 144.47 \\
$W_{6}$ & 58.96 & 37.04 & 21.92 & 10.96 & 143.76 \\
$W_{7}$ & 58.73 & 36.94 & 21.79 & 11.31 & 143.20 \\
$W_{8}$ & 58.54 & 36.86 & 21.69 & 11.60 & 142.73 \\
$W_{9}$ & 58.4 & 36.79 & 21.6 & 11.81 & 142.39 \\
$W_{10}$ & 58.27 & 36.74 & 21.54 & 12.01 & 142.08 \\
$W_{11}$ & 58.17 & 36.69 & 21.48 & 12.16 & 141.83 \\
$W_{12}$ & 58.09 & 36.66 & 21.43 & 12.28 & 141.64 \\
\hline
\end{tabular}

Table 8 are analyzed. When the thickness of EPS insulation layer increases, the total building energy consumption will decrease, bringing better building energy-saving effect. However, in the process of increasing the thickness of insulation layer, the decline range of building energy consumption gradually decreases. The variation of energy-saving rate can more directly show the overall situation of the total building energy consumption changing with the thickness of insulation layer. When the insulation layer reaches a certain thickness, the change of energy-saving rate tends to be in a straight-line form. This shows that the energy-saving effect achieved by increasing the thickness of insulation layer is not very outstanding, and the energy-saving benefit is not improved much, but will lead to higher reconstruction cost.

\subsubsection{Analysis of effect of energy-saving renovation of external window}

Windows could act as a mediator capable of not only reducing the load on the building but also improving the indoor environment by either allowing or blocking the passing of solar radiation 


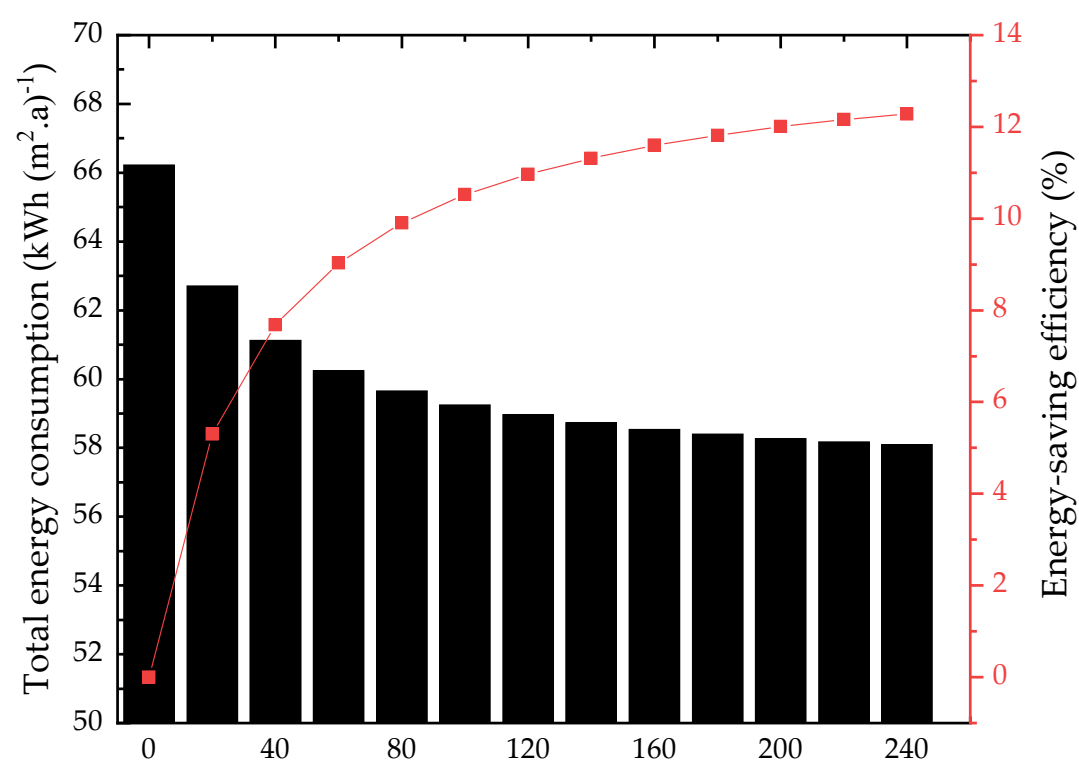

The thickness of EPS insulation board (mm)

Fig. 6. Change diagram of total energy consumption and energy-saving efficiency of external wall renovation scheme.

(Park et al., 2019). There are many factors to be considered in the energy-saving transformation of external windows, including heat transfer performance of external window glass and window frame profiles, shading performance of external windows and air tightness of external windows. In this study, only the heat transfer and energy absorption of the window are considered.

When analyzing the effect of external window renovation, the specification of the external wall and roof before renovation is kept to realize the qualitative analysis of a single variable. According to the common window frame profiles and glass configurations provided for reference in the "Guidelines" and in combination with the common window specifications and models on the market, six external window renovation schemes $C_{1}-C_{6}$ are selected, with the corresponding heat transfer coefficient of 2.4-1.0. The specific renovation schemes and their thermal performance are shown in Table 9.

The total energy consumption, cooling consumption, heating consumption and carbon dioxide emissions of each external window renovation schemes are shown in Table 10.

As we can see from Fig. 7 and Table 10, as the heat transfer coefficient of the external window gradually decreases, the total annual energy consumption of the building will decrease and the energy-saving rate will increase accordingly. However, different from the changing trend of the energy-saving transformation of the external wall and roof, the decrease of the heat transfer coefficient of the outer window will make the building energy consumption continue to decrease from 2.4 to $1.0 \mathrm{~W} \mathrm{~m}^{-2} \mathrm{~K}^{-1}$. It can be seen from the change of energy-saving rate that the energy consumption decreases with the decrease of the heat transfer coefficient, and the energy-saving rate gradually increases. When the heat transfer coefficient of the external window reaches $1.0 \mathrm{~W} \mathrm{~m}^{-2} \mathrm{~K}^{-1}$, the building energy-saving rate still keeps an upward trend, which can be speculated that the heat transfer coefficient of the external window of the building has a further downward space, and has a considerable potential for energy-saving transformation.

\subsubsection{Analysis of change rate of energy-saving renovation effect of building envelope}

According to the analysis of the energy-saving transformation effect of building external wall and roof, when the thickness of insulation layer increases to a certain extent, the decline rate of building energy consumption will gradually slow down. In order to explore the degree of its change, the external wall and roof energy-saving reconstruction was further analyzed. 
Table 9. Energy-saving and $\mathrm{CO}_{2}$ emissions reduction renovation scheme of existing building window.

\begin{tabular}{|c|c|c|}
\hline Renovation Scheme & Specification (from Top to Bottom) & $\begin{array}{l}\text { Heat Transfer Coefficient } \\
\left(\mathrm{W} \mathrm{m}^{-2} \mathrm{~K}^{-1}\right)\end{array}$ \\
\hline Pre-renovation & Single glazed aluminum window & 6.4 \\
\hline$C_{1}$ & $\begin{array}{l}\text { Single-silver low-emissivity glass: } 5 \mathrm{~mm} \\
\text { Air layer: } 12 \mathrm{~mm} \\
\text { Normal glass: } 5 \mathrm{~mm}\end{array}$ & 2.4 \\
\hline$C_{2}$ & $\begin{array}{l}\text { Double-silver low-emissivity glass: } 5 \mathrm{~mm} \\
\text { Air layer: } 12 \mathrm{~mm} \\
\text { Normal glass: } 5 \mathrm{~mm}\end{array}$ & 2.1 \\
\hline$C_{3}$ & $\begin{array}{l}\text { Triple-silver low-emissivity glass: } 5 \mathrm{~mm} \\
\text { Air layer: } 12 \mathrm{~mm} \\
\text { Normal glass: } 5 \mathrm{~mm}\end{array}$ & 1.9 \\
\hline$C_{4}$ & $\begin{array}{l}\text { Single-silver low-emissivity glass: } 5 \mathrm{~mm} \\
\text { Air layer: } 12 \mathrm{~mm} \\
\text { Normal glass: } 5 \mathrm{~mm} \\
\text { Air layer: } 12 \mathrm{~mm} \\
\text { Normal glass: } 5 \mathrm{~mm}\end{array}$ & 1.6 \\
\hline$C_{5}$ & $\begin{array}{l}\text { Triple-silver low-emissivity glass: } 5 \mathrm{~mm} \\
\text { Air layer: } 12 \mathrm{~mm} \\
\text { Normal glass: } 5 \mathrm{~mm} \\
\text { Air layer: } 12 \mathrm{~mm} \\
\text { Normal glass: } 5 \mathrm{~mm}\end{array}$ & 1.3 \\
\hline$C_{6}$ & $\begin{array}{l}\text { Normal glass: } 5 \mathrm{~mm} \\
\text { Air layer: } 12 \mathrm{~mm} \\
\text { Double-silver low-emissivity glass: } 5 \mathrm{~mm} \\
\text { Vacuum layer } \\
\text { Normal glass: } 5 \mathrm{~mm}\end{array}$ & 1.0 \\
\hline
\end{tabular}

Table 10. Annual energy consumption and carbon dioxide emissions after external window renovation.

\begin{tabular}{llllll}
\hline $\begin{array}{l}\text { Renovation } \\
\text { Scheme }\end{array}$ & $\begin{array}{l}\text { Total Energy } \\
\text { Consumption } \\
\left(\mathrm{kWh} \mathrm{m}^{-2}\right)\end{array}$ & $\begin{array}{l}\text { Cooling } \\
\text { Consumption } \\
\left(\mathrm{kWh} \mathrm{m}^{-2}\right)\end{array}$ & $\begin{array}{l}\text { Heating } \\
\text { Consumption } \\
\left(\mathrm{kWh} \mathrm{m}^{-2}\right)\end{array}$ & $\begin{array}{l}\text { Energy-saving } \\
\text { Efficiency } \\
(\%)\end{array}$ & $\begin{array}{l}\text { Carbon Dioxide } \\
\text { Emissions } \\
(\mathrm{t})\end{array}$ \\
\hline Pre-renovation & 66.22 & 40.35 & 25.87 & 0.00 & 161.46 \\
$C_{1}$ & 54.74 & 38.93 & 15.82 & 17.34 & 133.47 \\
$C_{2}$ & 53.25 & 35.89 & 17.36 & 19.59 & 129.84 \\
$C_{3}$ & 52.54 & 35.85 & 16.69 & 20.66 & 128.10 \\
$C_{4}$ & 51.41 & 35.78 & 15.62 & 22.36 & 125.35 \\
$C_{5}$ & 50.19 & 35.35 & 14.84 & 24.21 & 122.38 \\
$C_{6}$ & 49.01 & 35.3 & 13.7 & 25.99 & 119.50 \\
\hline
\end{tabular}

When the temperature of indoor and outdoor air exists difference, the process of heat transfer will be appeared. Under stable conditions, through the heat of the envelope, basic heating consumption, so the basic heating consumption of the envelope can be calculated according to Eq. (2):

$$
Q=\frac{a \cdot F \cdot \Delta t}{R_{1}+\frac{\delta}{\lambda}}
$$

where $Q$ is the basic heating consumption of envelope structure; $a$ is the temperature difference correction coefficient of envelope structure; $F$ is the area of envelope structure; $\Delta t$ is the temperature difference between indoor and outdoor; $R_{1}$ is the thermal resistance of building 


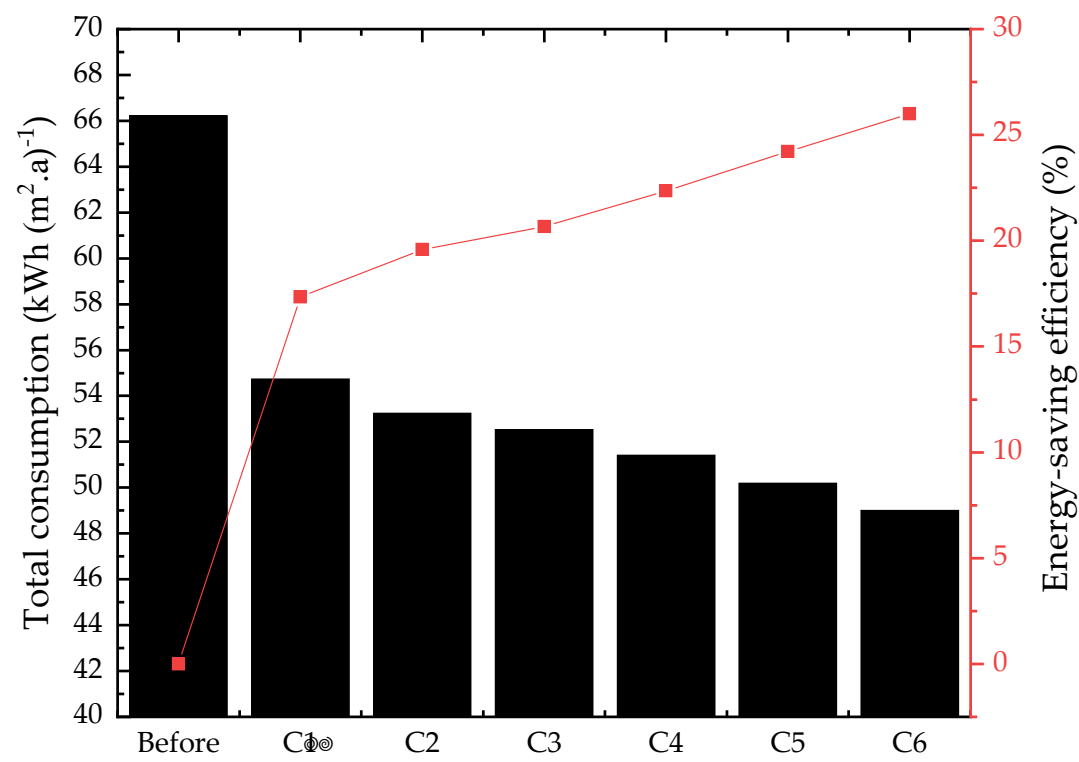

Renovation schemes of external window

Fig. 7. Change diagram of total energy consumption and energy-saving efficiency of external window renovation scheme.

envelope other than insulation layer; $\delta$ is the thickness of insulation layer; $\lambda$ is the heat transfer coefficient of insulation layer.

According to Eq. (2), the basic heating consumption of the envelope is related to the thickness of insulation materials. In order to analyze the impact of the thickness change of insulation layer on energy consumption and reasonably select the thickness of insulation layer, the concept of change rate of energy-saving is introduced. The relevant definition is shown in Eq. (3):

$\varphi=\frac{Q-Q_{t}}{\delta_{i}}$

where $\varphi$ is the energy-saving change rate; $Q$ is the energy consumption before renovation; $Q_{i}$ is the energy consumption with insulation thickness $\delta_{i} ; \delta_{i}$ is the thickness of insulation layer. The change rate of energy saving of external wall and roof are shown in Table 11.

According to Table 11, when the thickness of EPS insulation board increases gradually, the change in energy consumption brought by the unit thickness of insulation board decreases gradually. Since the renovation area of the external wall is twice the area of the roof, the change in energy consumption brought by the external wall is significantly higher than the impact of the roof.

For external wall, when the thickness of EPS insulation board changes from 0 to $120 \mathrm{~mm}$, the change rate of energy saving is obvious; when the thickness of EPS insulation board reaches $120 \mathrm{~mm}$, if the thickness of external wall insulation board is increased, the change range of energy-saving rate gradually slows down, while when the thickness of the insulation board changes between 180 and $240 \mathrm{~mm}$, increasing the thickness of the insulation board has a small change rate of energy saving. Even increasing the thickness of the insulation board, the change rate of energy saving remains unchanged and keeps a basically stable state. This indicates that the contribution of insulation board per unit thickness to building energy consumption reduction is getting smaller and smaller. Therefore, $120-\mathrm{mm}$-thick insulation board was selected as a more appropriate upper limit for the thickness of external wall insulation board. When the thickness of external wall insulation board is $120 \mathrm{~mm}$, the energy-saving change rate is 0.1 .

For the roof, similar to the external wall, when the thickness of EPS insulation board changes from 0 to $120 \mathrm{~mm}$, the change rate of energy saving is obvious; the thickness of EPS insulation board ranging from 140 to $240 \mathrm{~mm}$, the energy-saving rate of change to maintain a basically stable state, the change range is small. Therefore, $140 \mathrm{~mm}$ is selected as a more appropriate 
Table 11. Energy-saving change rate of external wall and roof.

\begin{tabular}{|c|c|c|c|c|c|c|}
\hline \multirow[b]{2}{*}{$\begin{array}{l}\text { The Thickness of } \\
\text { EPS Insulation } \\
\text { Board (m) }\end{array}$} & \multicolumn{3}{|c|}{ External Wall } & \multicolumn{3}{|c|}{ Roof } \\
\hline & $\begin{array}{l}\text { Heat Transfer } \\
\text { Coefficient } \\
\left(\mathrm{W} \mathrm{m}^{-2} \mathrm{~K}^{-1}\right)\end{array}$ & $\begin{array}{l}\text { Total Energy } \\
\text { Consumption } \\
\left(\mathrm{kWh} \mathrm{m}^{-2}\right)\end{array}$ & $\begin{array}{l}\text { Energy-saving } \\
\text { Change rate } \\
(\varphi)\end{array}$ & $\begin{array}{l}\text { Heat Transfer } \\
\text { Coefficient } \\
\left(\mathrm{W} \mathrm{m}^{-2} \mathrm{~K}^{-1}\right)\end{array}$ & $\begin{array}{l}\text { Total Energy } \\
\text { Consumption } \\
\left(\mathrm{kWh} \mathrm{m}^{-2}\right)\end{array}$ & $\begin{array}{l}\text { Energy-saving } \\
\text { Change Rate } \\
(\varphi)\end{array}$ \\
\hline 0 & 1.736 & 66.22 & - & $1.761 / 1.587$ & 66.22 & - \\
\hline 20 & 1.018 & 60.12 & 0.31 & $1.026 / 0.965$ & 62.71 & 0.18 \\
\hline 40 & 0.72 & 57.48 & 0.22 & $0.724 / 0.693$ & 61.13 & 0.13 \\
\hline 60 & 0.557 & 56.00 & 0.17 & $0.559 / 0.541$ & 60.24 & 0.10 \\
\hline 80 & 0.454 & 55.05 & 0.14 & $0.456 / 0.443$ & 59.66 & 0.08 \\
\hline 100 & 0.383 & 54.40 & 0.12 & $0.385 / 0.376$ & 59.25 & 0.07 \\
\hline 120 & 0.332 & 53.92 & 0.10 & $0.333 / 0.326$ & 58.96 & 0.06 \\
\hline 140 & 0.292 & 53.55 & 0.09 & $0.293 / 0.288$ & 58.73 & 0.05 \\
\hline 160 & 0.261 & 53.25 & 0.08 & $0.262 / 0.258$ & 58.54 & 0.05 \\
\hline 180 & 0.236 & 53.02 & 0.07 & $0.237 / 0.233$ & 58.40 & 0.04 \\
\hline 200 & 0.215 & 52.81 & 0.07 & $0.216 / 0.213$ & 58.27 & 0.04 \\
\hline 220 & 0.198 & 52.66 & 0.06 & $0.198 / 0.196$ & 58.17 & 0.04 \\
\hline 240 & 0.183 & 52.51 & 0.06 & $0.184 / 0.182$ & 58.09 & 0.03 \\
\hline
\end{tabular}

upper limit for the thickness of roof insulation board. When the thickness of roof insulation board is $140 \mathrm{~mm}$, the change rate of energy-saving is 0.05 .

\subsection{Economic Analysis of Energy-saving Renovation of Building Envelope}

The current European building stock is ageing and requires a "renovation wave" to improve its energy performance and ensure structural safety (Pohoryles et al., 2020). However, the research found that in China, retrofit of existing buildings generally lack of attractiveness to investors from an economic perspective (Liu et al., 2018). Therefore, it is necessary to consider not only the energy-saving effect achieved, but also the economy of the existing residential building envelope. In this paper, through the static payback period and dynamic payback period, the economy of the energy-saving transformation scheme is judged and selected.

\subsubsection{Design of orthogonal experiment scheme}

In order to meet the standard of passive ultra-low energy consumption for residential building, an appropriate envelope modification scheme was selected by referring to the upper limit reference value of heat transfer coefficient of building envelope in the "Guidelines," so as to determine the horizontal range of factors for the orthogonal test.

According to the "Guidelines," the scheme of optional external wall are $Q_{6}-Q_{12}$, the scheme of optional roof are $W_{6}-W_{12}$, the scheme of optional external window are $C_{3}-C_{6}$. Each factor is divided into working condition levels, and four working condition levels are selected. The simulation working condition factors and level selection table are shown in Table 12.

In this simulation study of the existing building envelope, only the influence of the heat transfer coefficient of the external wall, the roof and the external window on the building energy consumption are considered, and the interaction between the factors is not considered. The orthogonal design of the three-factor and four-level tests was carried out by using the software SPSS to replace the comprehensive test. The orthogonal table $L_{16}\left(4^{3}\right)$ was selected to conduct 16 simulations. The specific simulation conditions are shown in Table 13.

Table 12. Factors and level selection of simulated working conditions.

\begin{tabular}{llll}
\hline $\begin{array}{l}\text { Working Condition } \\
\text { Level }\end{array}$ & $\begin{array}{l}\text { External Wall } \\
(\mathrm{A} ; \mathrm{mm})\end{array}$ & $\begin{array}{l}\text { Roof } \\
(\mathrm{B} ; \mathrm{mm})\end{array}$ & $\begin{array}{l}\text { External Window } \\
\left(\mathrm{C} ; \mathrm{W} \mathrm{m}^{-2} \mathrm{~K}^{-1}\right)\end{array}$ \\
\hline 1 & 120 & 120 & 1.9 \\
2 & 160 & 160 & 1.6 \\
3 & 200 & 200 & 1.3 \\
4 & 240 & 240 & 1.0 \\
\hline
\end{tabular}


Table 13. $L_{16}\left(4^{3}\right)$ orthogonal array.

\begin{tabular}{llll}
\hline Simulated Working Conditions & External Wall $(\mathrm{A})$ & Roof $(\mathrm{B})$ & External Window $(\mathrm{C})$ \\
\hline 1 & 1 & 1 & 1 \\
2 & 2 & 2 & 1 \\
3 & 3 & 3 & 1 \\
4 & 4 & 4 & 1 \\
5 & 1 & 2 & 2 \\
6 & 2 & 1 & 2 \\
7 & 3 & 4 & 2 \\
8 & 4 & 3 & 2 \\
9 & 1 & 3 & 3 \\
10 & 2 & 4 & 3 \\
11 & 3 & 1 & 3 \\
12 & 4 & 2 & 3 \\
13 & 1 & 4 & 4 \\
14 & 2 & 3 & 4 \\
15 & 3 & 2 & 4 \\
16 & 4 & 1 & 4 \\
\hline
\end{tabular}

\subsubsection{Economic analysis of energy-saving renovation}

An orthogonal experiment is a fast, economical and efficient multi-factor test method. In this paper, the transformation cost refers to the average market price. Among them, the electricity price in Wuxi is USD $0.13 \mathrm{kWh}^{-1}$, the price of EPS insulation material is USD $76.62 \mathrm{~m}^{-3}$. Price of external window renovation $\left(C_{3}-C_{6}\right)$ are separately USD $101.29 \mathrm{~m}^{-2}$, USD $112.78 \mathrm{~m}^{-2}$, USD $151.4 \mathrm{~m}^{-2}$, USD $187.56 \mathrm{~m}^{-2}$. The simulation results and economic analysis of each working condition are shown in Table 14.

According to the total energy consumption, cooling consumption, heating consumption, carbon dioxide emissions and static recovery period, the corresponding orthogonal intuitive optimal scheme and orthogonal horizontal optimal scheme were selected, as shown in Table 15.

Meanwhile, considering the economy of the energy-saving and carbon dioxide emissions reduction renovation, the static payback period was selected as the evaluation index to determine the optimal scheme. The dynamic payback period of the two optimal schemes was calculated, and the optimal scheme of the energy-saving transformation was finally selected. The comparison results of the comprehensive transformation schemes are shown in Table 16.

According to the comparison of the static recovery period and dynamic recovery period of the two schemes, it can be concluded that A1B1C1 is the optimal economic recovery scheme. The specific methods of its transformation scheme are as below. The thickness of EPS insulating board of both external wall and roof is $120 \mathrm{~mm}$. The specification of external window is triple-silver lowemissivity glass $(5 \mathrm{~mm})+$ air layer $(12 \mathrm{~mm})+$ normal glass $(5 \mathrm{~mm})$.

\subsection{Analysis of Environmental Benefit}

Electricity is a form of energy which is essential in our daily life and electricity generation mainly comes from the burning of coal. According to the analysis above, through renovation of building envelope, energy consumption of heating and cooling during the building operation can be reduced, and the power consumption can be saved, thus reducing the emission of greenhouse gases such as carbon dioxide and dust. China has suffered from extensive air pollution and subsequent severe outcomes, such as impeded socioeconomic development, in recent years (Liu et al., 2020b; Wang et al., 2021; Wu et al., 2021). The software BESI is used to simulate the actual energy consumption of the above optimal renovation scheme. The comparison of building energy and power consumption before and after renovation can be obtained, as shown in Figs. 8(a) and 8(b). As shown in Fig. 9, the pollutant emission is reduced by a great amount after renovation. According to the simulation, the optimal retrofit scheme can save $16.6 \mathrm{kWh} \mathrm{m}^{-2}$ of electricity consumption every year, which has remarkable environmental benefits. Meanwhile, $\mathrm{CO}_{2}$ emissions could be reduced by 86.01 tons, $\mathrm{SO}_{2}$ emissions could be by 2.59 tons, and nitrogen oxide emissions could be by 1.29 tons per year. 


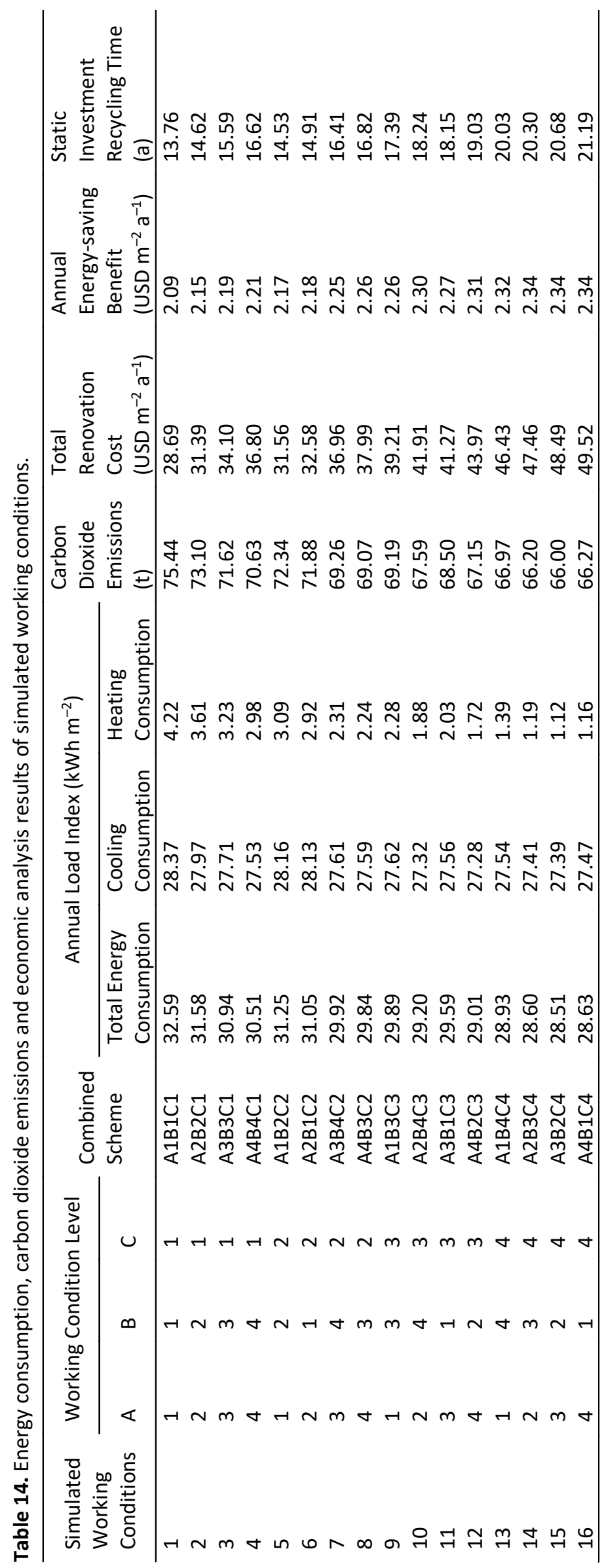


Table 15. Pre-selection of the optimal scheme.

\begin{tabular}{lll}
\hline Evaluation Index & Orthogonal Intuitive Optimal Scheme & Orthogonal Horizontal Optimal Scheme \\
\hline Total energy consumption & A3B2C4 & A4B4C4 \\
Cooling consumption & A4B2C3 & A4B4C3 \\
Heat consumption & A3B2C4 & A4B4C4 \\
Carbon dioxide emissions & A3B2C4 & A4B4C4 \\
Static investment recycling time & A1B1C1 & A1B1C2 \\
\hline
\end{tabular}

Table 16. Comprehensive comparison of reconstruction schemes.

\begin{tabular}{|c|c|c|c|c|c|}
\hline Scheme Type & $\begin{array}{l}\text { Specific } \\
\text { Scheme }\end{array}$ & $\begin{array}{l}\text { Total } \\
\text { Renovation Cost } \\
\left(\text { USD m }{ }^{-2} \mathrm{a}^{-1}\right)\end{array}$ & $\begin{array}{l}\text { Energy-saving } \\
\text { Benefit } \\
\left(\text { USD m }{ }^{-2} \mathrm{a}^{-1}\right)\end{array}$ & $\begin{array}{l}\text { Static Investment } \\
\text { Recycling Time } \\
\text { (a) }\end{array}$ & $\begin{array}{l}\text { Dynamic Investment } \\
\text { Recycling Time } \\
\text { (a) }\end{array}$ \\
\hline $\begin{array}{l}\text { Orthogonal intuitive } \\
\text { optimal scheme }\end{array}$ & A1B1C1 & 28.69 & 2.09 & 13.76 & 22.84 \\
\hline $\begin{array}{l}\text { Orthogonal horizontal } \\
\text { optimal scheme }\end{array}$ & $\mathrm{A} 1 \mathrm{~B} 1 \mathrm{C} 2$ & 30.72 & 2.15 & 14.30 & 24.50 \\
\hline
\end{tabular}

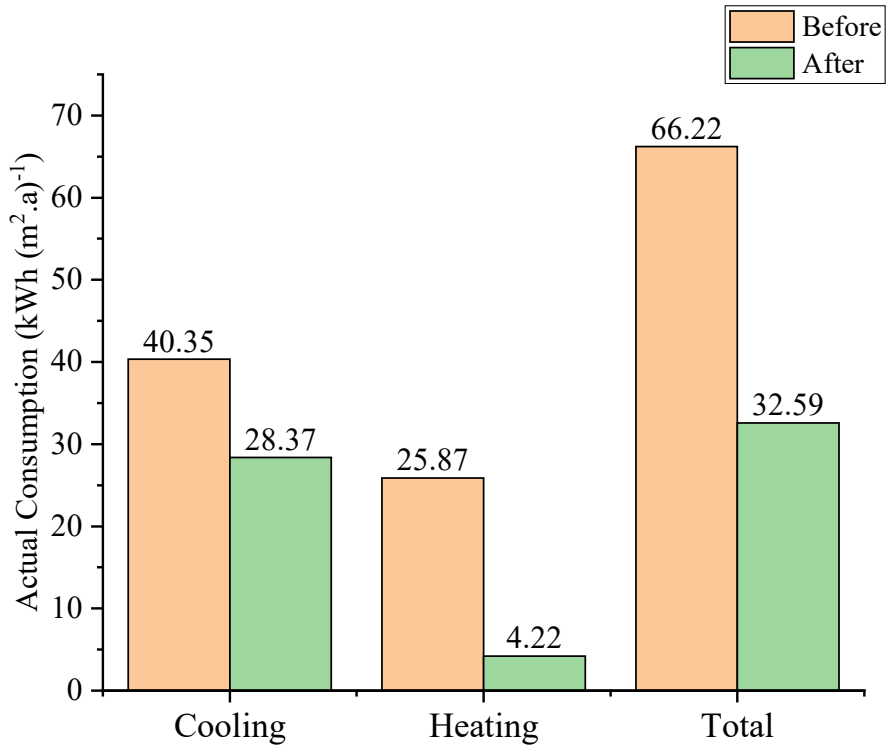

(a) Comparison of energy consumption

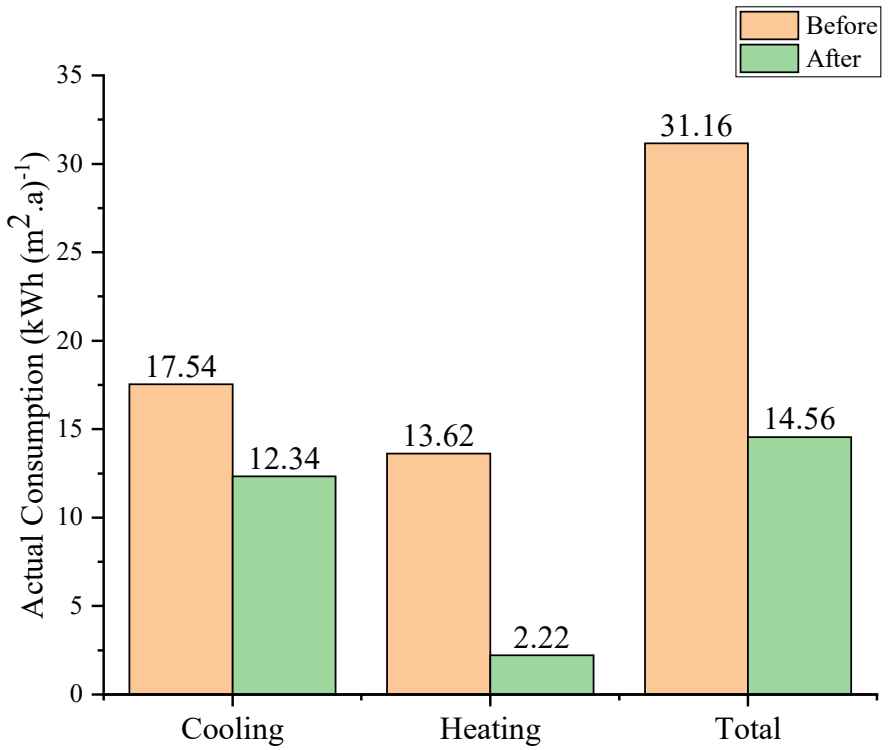

(b) Comparison of power consumption

Fig. 8. Comparison of (a) energy and (b) power consumption before and after the optimal renovation scheme.

\section{CONCLUSIONS}

We evaluated various energy-saving renovation schemes for an existing residential building in an area with hot summers and cold winters by using the relevant standards and specifications, the software BESI, and the orthogonal test method to set various parameters, simulate the building's energy consumption, and conduct an economic analysis, respectively. Our findings can be summarized as follows.

(1) Based on our individual analysis of each scheme, the building's energy consumption decreased with the envelope element's heat transfer coefficient. However, the conservation effect gradually diminished as the thickness of the insulation layer for the exterior wall and the roof increased.

(2) We simulated the effects of combining different schemes by employing the orthogonal test method and setting the static payback period (the time required to recover the invested capital) as the evaluation index. The optimal combination in terms of both cost and energy 


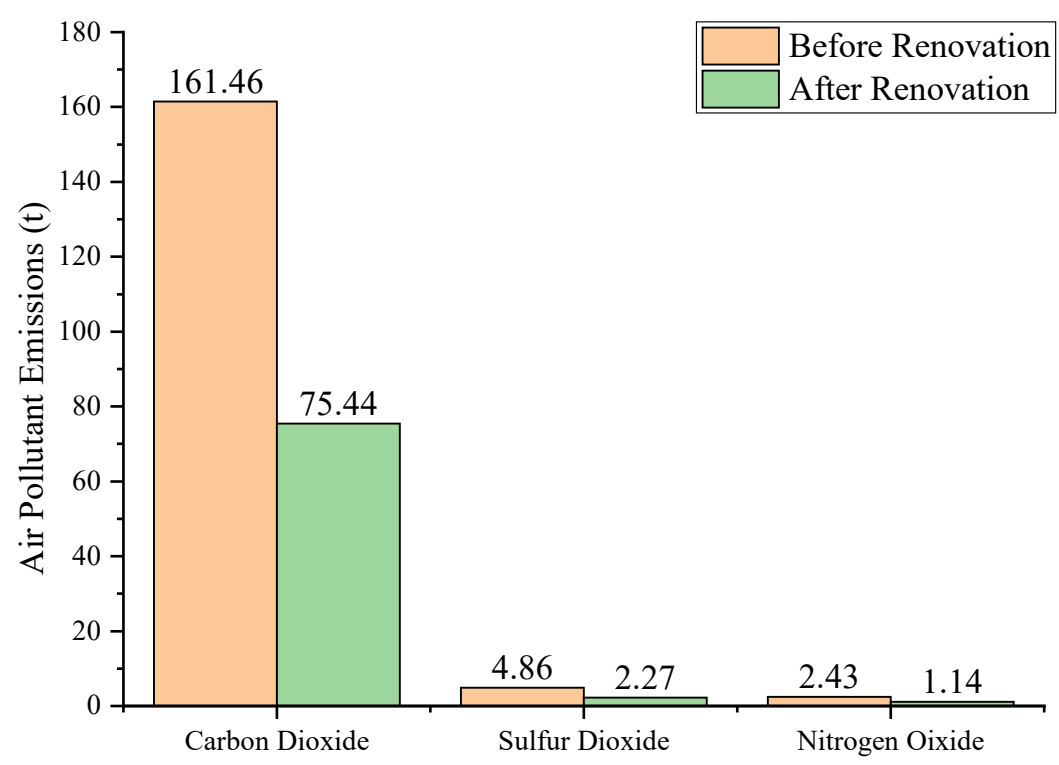

Fig. 9. Comparison of air pollutant emissions before and after renovation.

Table 17. The optimal renovation scheme.

\begin{tabular}{|c|c|c|}
\hline Building Envelope & Renovation Scheme & 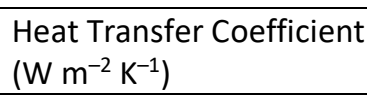 \\
\hline External wall & EPS insulation board: $120 \mathrm{~mm}$ & 0.332 \\
\hline External window & $\begin{array}{l}\text { Triple-silver low-emissivity glass: } 5 \mathrm{~mm} \\
\text { Air layer: } 12 \mathrm{~mm} \\
\text { Normal glass: } 5 \mathrm{~mm}\end{array}$ & 1.900 \\
\hline Roof & EPS insulation board: $120 \mathrm{~mm}$ & $\begin{array}{l}\text { Flat roof: } 0.333 \\
\text { Slope roof: } 0.326\end{array}$ \\
\hline
\end{tabular}

efficiency (Table 17) resulted in a cooling capacity, heating consumption, total building energy consumption, static payback period, and dynamic payback period of $28.37 \mathrm{kWh} \mathrm{m}^{-2} \mathrm{a}^{-1}$, $4.22 \mathrm{kWh} \mathrm{m}^{-2} \mathrm{a}^{-1}, 32.59 \mathrm{kWh} \mathrm{m}^{-2} \mathrm{a}^{-1}, 13.76$ years, and 22.84 years, respectively.

(3) This combination also reduced the annual emissions of $\mathrm{CO}_{2}, \mathrm{SO}_{2}$, and $\mathrm{NO}_{x}$ by 86.01 tons, 2.59 tons, and 1.29 tons, respectively, which offers substantial environmental benefits.

\section{REFERENCES}

Ahmed, W., Asif, M. (2020). BIM-based techno-economic assessment of energy retrofitting residential buildings in hot humid climate. Energy Build. 227, 110406-110419. https://doi.org/ 10.1016/j.enbuild.2020.110406

Al-Qahtani, L.A.H., Elgizawi, L.S.E. (2020). Building envelope and energy saving case study: a residential building in Al-Riyadh, Saudi Arabia. Int. J. Low-Carbon Technol. 15, 555-564. https://doi.org/10.1093/ijlct/ctaa024

Baglivo, C., Congedo, P.M., Cataldo, M.D., Coluccia, L.D., D'Agostino, D. (2017). Envelope design optimization by thermal modelling of a building in a warm climate. Energies 10, 1808. https://doi.org/10.3390/en10111808

Beidari, M., Lin, S.J., Lewis, C. (2017). Multiplier effects of energy consumption and $\mathrm{CO}_{2}$ emissions by input-output analysis in south Africa. Aerosol Air Qual. Res. 17, 1666-1678. https://doi.org/ 10.4209/aaqr.2017.04.0150

Cai, L., Feng, X.P., Yu, J.Y., Xiang, Q.C., Chen, R. (2019). Reduction in carbon dioxide emission and energy savings obtained by using a green roof. Aerosol Air Qual. Res. 19, 2432-2445. https://doi.org/10.4209/aaqr.2019.09.0455 
Chen, B., Li, D., Li, Q. (2017). Comprehensive benefit analysis on energy-saving renovation of existing residential buildings in hot summer and cold winter zone. Build. Sci. 33, 42-48. https://doi.org/10.13614/j.cnki.11-1962/tu.2017.08.07

Hamburg, A., Kalamees, T. (2019). How well are energy performance objectives being achieved in renovated apartment buildings in Estonia? Energy Build. 199, 332-341. https://doi.org/10. 1016/j.enbuild.2019.07.006

Lee, C.M., Rosalez, E.R. (2017). Economic growth, carbon abatement technology and decoupling strategy - The case of Taiwan. Aerosol Air Qual. Res. 17, 1649-1657. https://doi.org/10.4209/a aqr.2016.11.0487

Li, Z., Yao, H., Lan, C., Lei, W., Dong, F. (2018). Emission factors of $\mathrm{NO}_{x}, \mathrm{SO}_{2}$, and PM for bathing, heating, power generation, coking, and cement industries in Shanxi, China: Based on field measurement. Aerosol Air Qual. Res. 18, 3115-3126. https://doi.org/10.4209/aaqr.2018.08.0 282

Liu, D., Vonwiller, M., Li, J., Liu, J., Szidat, S., Zhang, Y., Tian, C., Chen, Y., Cheng, Z., Zhong, G., Fu, P., Zhang, G. (2020a). Fossil and non-fossil fuel sources of organic and elemental carbonaceous aerosol in Beijing, Shanghai, and Guangzhou: Seasonal carbon source variation. Aerosol Air Qual. Res. 20, 2495-2506. https://doi.org/10.4209/aaqr.2019.12.0642

Liu, T., Ye, S., Liu, Y. (2018). Cost-benefit analysis for energy efficiency retrofit of existing buildings: A case study in China. J. Cleaner Prod. 177, 493-506. https://doi.org/10.1016/j.jclep ro.2017.12.225

Liu, Z., Wang, Q., Gan, V.J.L., Peh, L. (2020b). Envelope thermal performance analysis based on building information model (BIM) cloud platform-Proposed green mark collaboration Environment. Energies 13, 586. https://doi.org/10.3390/en13030586

Mahmoodzadeh, M., Gretka, V., Wong, S., Froese, T., Mukhopadhyaya, P. (2020). Evaluating patterns of building envelope air leakage with infrared thermography. Energies 13, 3545. https://doi.org/10.3390/en13143545

Mancini, F., Nastasi, B. (2019). Energy retrofitting effects on the energy flexibility of dwellings. Energies 12, 2788. https://doi.org/10.3390/en12142788

Mejjaouli, S., Alzahrani, M. (2020). Decision-making model for optimum energy retrofitting strategies in residential buildings. Sustainable Prod. Consumption 24, 211-218. https://doi.org/ 10.1016/j.spc.2020.07.008

Park, B.R., Hong, J., Choi, E.J., Choi, Y.J., Moon, J.W. (2019). Improvement in energy performance of building envelope incorporating electrochromic windows (ECWs). Energies 12, 1181. https://doi.org/10.3390/en12061181

Pinto, J.F., da Graça, G.C. (2018). Comparison between geothermal district heating and deep energy refurbishment of residential building districts. Sustainable Cities Soc. 38, 309-324. https://doi.org/10.1016/j.scs.2018.01.008

Pohoryles, D.A., Maduta, C., Bournas, D.A., Kouris, L.A. (2020). Energy performance of existing residential buildings in Europe: $A$ novel approach combining energy with seismic retrofitting. Energy Build. 223, 110024-110043. https://doi.org/10.1016/j.enbuild.2020.110024

Puko, Z., Mauec, D., Uman, N. (2020). Energy and cost analysis of building envelope components using BIM: A systematic approach. Energies 13, 2643. https://doi.org/10.3390/en13102643

$\mathrm{Su}$, W., Wang, R., Zhao, T. (2020). $\mathrm{CO}_{2}$-imprinted sustainable carbon derived from sunflower heads for highly effective capture of $\mathrm{CO}_{2}$ from flue gas. Aerosol Air Qual. Res. 20, 180-192. https://doi.org/10.4209/aaqr.2019.10.0538

Szirtesi, K., Igaz, T. (2016). Airborne particulate matter investigation in buildings with passive house technology in Hungary. Aerosol Air Qual. Res. 18, 1282-1293. https://doi.org/10.4209/a aqr.2017.05.0158

Tan, H., Hao, X., Long, P., Xing, Q., Hu, J. (2019). Building envelope integrated green plants for energy saving. Energy Explor. Exploit. 38, 222-234. https://doi.org/10.1177/0144598719875529

Tokbolat, S., Nazipov, F., Kim, J.R., Karaca, F. (2019). Evaluation of the environmental performance of residential building envelope components. Energies 13, 174. https://doi.org/10.3390/en130 10174

Wang, Y., Zhang, Y., Li, X., Cao, J. (2021). Refined source apportionment of atmospheric $\mathrm{PM}_{2.5}$ in a typical city in northwest China. Aerosol Air Qual. Res. 21, 200146. https://doi.org/10.4209/a aqr.2020.04.0146 
Wu, Y., Zhan, Q., Zhao, Q. (2021). Long-term air pollution exposure impact on COVID-19 morbidity in China. Aerosol Air Qual. Res. 21, 200413. https://doi.org/10.4209/aaqr.2020.07.0413

Xiang, Q.C., Feng, X.P., Jia, X.Y., Cai, L., Chen, R. (2019). Reducing carbon dioxide emissions through energy-saving renovation of existing buildings. Aerosol Air Qual. Res. 19, 2732-2745. https://doi.org/10.4209/aaqr.2019.10.0503

Yang, D., Li, Q., Zhang, L. (2019). Characteristics of carbon dioxide emissions from a seismically active fault. Aerosol Air Qual. Res. 19, 1911-1919. https://doi.org/10.4209/aaqr.2019.06.0282

Yu, J., Yang, C., Tian, L., Liao, D. (2009). Evaluation on energy and thermal performance for residential envelopes in hot summer and cold winter zone of China. Appl. Energy 86, 19701985. https://doi.org/10.1016/j.apenergy.2009.01.012

Zhou, Z., Wang, C., Sun, X., Gao, F., Feng, W., Zillante, G. (2018). Heating energy saving potential from building envelope design and operation optimization in residential buildings: A case study in northern China. J. Cleaner Prod. 174, 413-423. https://doi.org/10.1016/j.jclepro.2017.10.237 